\title{
Exploiting context-dependent preferences to protect borrowers
}

\author{
Linda Dezső'1] $\cdot$ Barna Bakó² $\cdot$ Gábor Neszveda ${ }^{3}$
}

Received: 3 May 2021 / Revised: 21 September 2021 / Accepted: 5 November 2021 / Published online: 22 November 2021

(c) The Author(s) 2021

\begin{abstract}
Focusing bias is one of the key contributors to over-borrowing. It describes how people, when making choices, give disproportionate attention and weight to attributes in which their options differ more. In a loan decision, a consumer excessively focuses on the eye-catching difference between getting the loan and not getting it, while ignoring the smaller differences between making and not making repayments. Here, we show a simple trick that nudges the consumer to increase attention on the repayment dimension. In two experimental studies involving one hypothetical loan decision, we demonstrate that the salience of getting the loan can be decreased if one offered plan includes high initial installments. This steeply decreasing installment plan (i.e., with initially high installments that decrease over time) offered alongside the usual flat installments plan (i.e., with equally sized repayments through the whole term) increases consumers' attention to making repayments, and consequently, they attend less to obtaining the loan. When the choice set includes the steeply decreasing plan, we observe a decreased preference for the flat installment plan and a shift toward not borrowing. Additionally, making repayments on the loan is perceived as a greater burden, and more attention is given to making repayments when the steep plan is present. Policy may combat harmful loan consumption by prescribing the presentation of loan offers such that at least one option includes high initial repayments, which increases attention on making repayments.
\end{abstract}

Keywords Focusing illusion $\cdot$ Loan decisions $\cdot$ Consumer protection $\cdot$ Choice architecture $\cdot$ Loans $\cdot$ Defaulting $\cdot$ Mandatory disclosures

JEL Classification D15 · D18

\section{Introduction}

Harmful loan consumption or overborrowing is described as taking out a loan on which one eventually defaults (Friztdixon et al. 2014). The prevalence of loan delinquencies has been increasing since the 1990s (Federal Reserve Bank of New York 2020). Loan defaults are, however, not equally likely to occur for everyone. Due to limited financial resources, low-income households have an elevated risk

Linda Dezső

linda.dezsoe@univie.ac.at

1 Vienna Center for Experimental Economics, University of Vienna, Oskar Morgenstern Platz 1, 5.313, 1090 Vienna, Austria

2 Faculty of Economics and Business, John von Neumann University, Izsáki út 10, Kecskemét 6000, Hungary

3 MNB Department, Corvinus University of Budapest, Fővám tér 8, Budapest 1093, Hungary of experiencing loan defaults and financial vulnerability in general related to debt products (Kim et al. 2017). Indeed, Vihriälä (2021) reports, for instance, that younger people with larger families, with relatively little liquid assets and more interest-paying unsecured debts, were the ones opting for a short-term (i.e., six to twelve months) principle payment reliefs offered by Finnish banks in 2015. Consistent with these, Xiao and Yao (2014) report that younger, lower-income and non-white people with larger families are experiencing increasing hardships in making repayments on their auto or durable good loans. ${ }^{1}$ These facts call for riskmitigating measures and interventions for those in vulnerable positions (e.g., Ritholtz 2016).

Although people with lower socioeconomic status are more susceptible to defaulting on a loan, the reasons for loan delinquencies seem universal. On the one hand, many

\footnotetext{
${ }^{1}$ In this research, we only consider loans for durable goods and exclude mortgages because real-estate loans could be considered as investments. This aspect may introduce a strategic complexity to the choice of borrowing, a topic that is not covered in our research.
} 
loan defaults are caused by unforeseeable negative income shocks (Getter 2003; Collins et al. 2017). On the other hand, research in behavioral economics has identified several biases exerting effects when the loan decision is made, which account for suboptimal choices. Among these biases, present bias (e.g., Frederick et al. 2008; Meier and Sprenger 2012; Strotz 1955) and focusing illusion or focusing bias (e.g., Friztdixon et al. 2014; Kőszegi and Szeidl 2013) play key roles in overborrowing. Moreover, overoptimism (Hynes 2004; Brown et al. 2005; Dezsô and Loewenstein 2012; Dezső and Kirchler 2013) and overconfidence (Perry 2008; Robb et al. 2015; Vihriälä 2021) regarding the ability to repay a loan are also key contributors to premature loan consumption. These latter two biases are, however, not the focus of our research.

Focusing illusion describes how people making choices give disproportionate attention and weight to attributes in which their options differ more, as these attributes become salient in the process of comparing options to each other (Kahneman et al. 2006). These salient attributes then systematically drive the choice. In a loan decision, consumers attend excessively to (i.e., focus more on) the difference between getting the loaned amount and not, while attending much less to the remote and seemingly minor differences between making and not making repayments. Consequently, the consumer maximizes his/her focus-weighted utility on the spot of a loan decision, which falls below what s/he realizes with the consumption after the selected option is removed from the choice set (Kőszegi and Szeidl 2013; Friztdixon et al. 2014; Bakó et al. 2018).

The existence of focusing illusion demonstrates that preferences are susceptible to context and, as advanced in the research on context-dependent preferences, preferences may systematically change as the context changes (e.g., Tversky et al. 1990). The upside of this context dependence is that it can be advantageously exploited, as one can arrange the context so that it steers the consumer toward a less biased choice (Thaler et al. 2010). In particular, we argue and demonstrate that carefully designing the context in which loan plans are offered could result in a systematic change in the preference for loan consumption, and ultimately deter consumers from borrowing. This idea was first fleshed out in a theoretical paper by Bakó et al. (2018), henceforth denoted as BND.

The upshot of BND's model is offering the set of options in a loan decision such that the relative salience of obtaining the loan at the first time point is dampened by making the repayments at the subsequent time points more salient. According to BND's reasoning, this would decrease consumers' attention to the initial attribute with the large relative advantage (i.e., the time point of obtaining the loan) while increasing their attention to making repayments that are presented on the more distant but numerous attributes of borrowing (i.e., time points of the scheduled repayments).
Simply said, when repayment installments loom largely enough, consumers increase their attention to the repayments, which simultaneously decreases their attention to obtaining the loan. As a result, consumers would distribute their attention to their options in a more balanced fashion instead of giving disproportionate focus on the concentrated and salient benefit in the first dimension. BND argues that this intervention would mitigate focusing bias and the utility that consumers maximize during the loan decision would be more consistent with what they eventually realize in their consumption utility.

The technical solution proposed by BND is to offer a steeply decreasing installment plan (henceforth, steep plan) alongside the conventional flat installment plan (henceforth, flat plan) while always allowing for no borrowing. ${ }^{2}$ BND argues that the steep plan would increase the attention to repaying the loan because it entails high initial installments, which counterbalances the eye-catching nature of the (first) time point in which consumers would obtain the loan. Consequently, consumers would attend more to the repayment, which would make obtaining the loan (and the good) less salient. In other words, the advantage of obtaining the loan over not obtaining it would not stand out so much because the disadvantage of paying large installments over paying zero or smaller installments would also stand out. This way, the seemingly large advantage of getting the loan over not getting it would be dampened. In short, offering a steep plan and a flat plan simultaneously would mitigate the influence of focusing illusion by directing attention to the loan's repayment.

The goal of this paper is to empirically test BND's theoretical propositions. We first adapt their model to fit our experimental testing. Next, we present the results of two online experiments involving hypothetical scenarios, requiring one choice of whether or not to finance a purchase from a loan and self-reports of the perceived burdens of the offered loan plans and attention assigned to obtaining the loan and the repayments. In both studies, we use purchase scenarios involving durable goods: a car in Study 1 and a laptop in Study 2.

The results of both studies demonstrate that the presence of the steep plan decreases the likelihood of borrowing under the flat plan and shifts consumers' preferences toward not borrowing from choosing the flat plan. Moreover, we found that the presence of the steep plan affects the perceptions of the flat plan: when the steep plan is presented alongside

\footnotetext{
${ }^{2}$ By flat plan, we mean a repayment schedule with equal installment sizes over the repayment period. Empirical investigations show that people have a strong preference for a flat plan over any other ones. This is because the flat plan enables consumers to anticipate the loan's monthly cost and factor these costs into their budgets (Cox, Brounen and Neuteboom, 2015).
} 
the flat plan, subjects rate the burden of making repayments under the flat plan as being higher and report shifting their attention from obtaining the good to making repayments. We also found that these mechanisms are robust after controlling for participants' real-life plans to finance a laptop purchase from a loan in the next 12 months.

In what follows, we review some relevant literature to motivate our studies. Next, we describe the designs and the methods of the two experiments. Then, we present the results of both studies. Finally, we discuss our results, the limitations, and conclude.

\section{Some relevant literature}

We first present some literature on loan decisions and how they are modeled in economic psychology. Here, we summarize how loan products are evaluated and compared to each other and how context plays a crucial role in this evaluation. We also describe how focusing illusion plays out in loan decisions. This is followed by reviewing the mandatory disclosure policies and their effectiveness. Then, we present the BND framework to motivate our empirical setup.

\section{The psychology of loan decisions}

A loan is an intertemporal sequence entailing a relatively large benefit at one specific time point (when an individual obtains the loan and makes the purchase) and many, relatively small costs (i.e., repayments) spread over subsequent time points. A present-biased consumer values obtaining the loan more than its overall costs and hence is likely to default on making repayments (e.g., Neszveda and Dezső 2012). This mechanism is supported by process-oriented research on loan decisions documenting that, when signing up for a loan, people are prone to underestimate the burden and the cost of repayments, which then loom when they become imminent (Hoelzl, Pollai and Kamleitner, 2009).

Another important aspect of the loan decision-making process is that consumers are inclined to compare their options (including the option of not borrowing and thus not purchasing) to each other and evaluate them on their mutual attributes (Kamleitner and Kirchler 2006; Hoelzl et al. 2009; Kamleitner et al., 2010; Hoelzl et al. 2011; Kőszegi and Szeidl, 2013; Bakó et al., 2018). Consequently, they compare the available options to each other and choose the option which seems to bring them the highest benefit within the set. In these comparisons, the time points in which benefits (i.e., obtaining the loan and making the purchase) and costs (i.e., making repayments) occur are viewed as the mutual attributes of the options, and consumers compare the values of each attribute moving from one attribute to the other. What is implicit in such an attribute-by-attribute processing mode is that when consumers make a choice, they do not just evaluate their options in isolation but instead, they construct their preferences based on the outcomes of these comparisons, which are inevitably susceptible to the context of the available options (Slovic 1995; Weber and Johnson 2009; Vlaev et al. 2011).

One way to create a context for choices is by presenting alternatives jointly rather than sequentially. Hsee et al. (1999) systematically examine preferences for alternatives across joint and separate presentations and find robust, systematic preference reversals between the two presentation modes. The authors find that during a joint presentation, people tend to identify the mutual attributes of the alternatives and evaluate the options with respect to each other as opposed to independently. One consequence of evaluating options with respect to each other is that options with salient attributes receive more focus are overweighted, and hence the utility that is being maximized when the choice is made is weighted with the focus. This so-called focusing illusion (Kahneman et al. 2006) has been documented in the psychological literature leading to suboptimal food choices (Abaluck 2011), biased evaluations of life satisfaction (Schkade and Kahneman 1998), and choices between accommodations (Dunn et al. 2003).

Kőszegi and Szeidl (2013), henceforth KS, propose a theoretical framework to model focusing illusion in intertemporal choice. Their model proposes that when consumers are offered a choice between simultaneously presented intertemporal sequences, they tend to compare their alternatives on their mutual attributes and focus on the relatively large attribute differences while putting less weight on attributes in which their options differ less. Applying the KS model to a loan decision proceeds as follows: in a binary choice set of borrowing under a specific loan plan or not borrowing (and hence, not consuming), the consumer focuses more on the large positive attribute (i.e., the first time point when s/he receives the loan and hence consumes) and less on the small but numerous negatives ones (i.e., the monthly repayments). That is, the large initial advantage of borrowing over not borrowing attracts the consumer's attention and biases his/ her choice toward signing up for a loan. In this context, consumers underappreciate the burden of making repayments relative to the benefit of receiving the loaned amount, not only because they are present biased but also because they evaluate options jointly and interdependently rather than sequentially and independently.

\section{The effectiveness of loan disclosure policies}

It seems that loan decisions are not only challenging for consumers because they tend to be overconfident about their ability to make repayments (Vihriälä 2021) and because they may succumb to focusing illusion, but also because they 
seem to be lost in the forest of information and complexity. To mitigate the hardships due to the complexity of loan contracts and also to protect borrowers against inaccurate and unfair credits, in 1968 the so-called Truth in Lending Action (TILA; 15 U.S.C. 1601 et seq.) was enacted. TILA was introduced on the federal level in the United States and is therefore mandatory nationwide. TILA prescribes mandatory disclaimers and disclosures from lenders for certain loans such as consumer credit and real-estate loans. These disclosures must include the total cost of the loan, the annual percentage rate (APR), all possible charges including potential penalties and fees, and the payment schedule (for more information, see, https://www.debt.org/credit/your-consu mer-rights/truth-lending-act/ and https://www.occ.treas. gov/topics/consumers-and-communities/consumer-prote ction/truth-in-lending/index-truth-in-lending.html). Unfortunately, however, the effectiveness of these disclosures is not clear from the literature. In particular, the question is what proportion of the presented information is internalized by the consumer and how much information is needed to achieve more prudent choices.

Perry and Blumenthal (2012) review existing literature on mandatory disclosures for mortgages and conclude that consumers are confused by the amount and the complexity of the information presented. Additionally, they find a lack of conclusive evidence on how disclosures influence choices and how they interact with social and contextual features. Directly addressing the effectiveness of mandatory disclosures on mortgages, Lacko and Pappalardo (2010) conduct a randomized experiment with more than 800 mortgage borrowers along with in-depth, qualitative interviews with a large sample of other borrowers. They find that it is not the cognitive overload or the complexity of the disclosures which are associated with defaulting. Instead, the disclosures were purely designed, missing key information or being confusing and including misleading information. The authors conclude that borrowers would be best served by one single document that conveys the key loan terms in an easy-tounderstand fashion.

\section{A simple intervention to increase attention on the loan's cost}

Along the lines of Lacko and Pappalardo (2010), BND adapts the KS model for loan decisions to an environment where multiple loans are offered. They propose that focusing illusion could be mitigated in a loan decision, making harmful loan consumption less likely to occur, if the set of the offered loan plans included a plan that increases attention to the loan's costs (i.e., repayment dimension). This low-cost approach may nudge consumers toward a less biased choice without changing the incentives or prohibiting them to borrow (e.g., Thaler et al. 2010). Nudging has been successfully used to increase the retirement savings of workers who otherwise had challenges in saving for their senior years (Thaler and Benartzi 2004), and has also been welcomed as an intervention technique in financial decisions where biased decisions can be particularly costly in the long run for consumers (e.g., Cai 2019).

Technically, BND proposes adding a specific third plan to the binary choice set consisting of not borrowing, or borrowing under a typical flat plan in which the consumer pays equally sized installments until the end of the term. This third plan should be designed such that it increases attention to the loan's cost and hence leaves less attention to the attribute of obtaining the loan. BND proposes that this third alternative should ideally be a steep plan that starts with high installments which then decrease over time to the point where they are below the flat plan's installments. Note that KS and the BND models are agnostic about whether the consumers first discount the loan's consumption utility and then weigh it with the focus weight or vice versa. Both models lead to identical behavioral predictions under either order.

In testing BND's approach, however, we must control for the increase in the choice sets' cardinality, since adding the steep plan results in more available choices-a potential confound. To eliminate this confound, we adapt the BND model. The gist of the adaptation is that we add a condition in which a slightly decreasing installment plan (henceforth, slight plan) is offered alongside the flat plan. This solution enables us to separate the effect of extending the set (i.e., increasing the set's cardinality) from that of increasing the repayments' salience. In line with BND, we assume that in this slight plan, repayments are insufficiently salient and thus would neither influence the preference for the flat plan nor increase attention to the attributes of the repayments. In Appendix A, we provide the theoretical model and propositions of the choice dynamics under the addition of the slight and steep plans, to motivate our empirical hypotheses.

In two studies, we first test that when the steep plan is added to the choice set, consumers will be less likely to opt for the flat plan compared to the situation when the steep plan is not offered, and also that consumers would systematically shift their preferences toward not borrowing from borrowing under the flat plan. The reason why we investigate how preferences for the flat plan changes due to this manipulation is because empirical research suggests that, regardless of income level or other demographic characteristics, consumers prefer flat plans over decreasing or increasing installment plans (Montezemolo 2012; Cox et al. 2015). This expectation may also appeal to common sense: if consumers can pay large installments early, as offered in the steep or slight plan, they might also make a larger downpayment, which would provide access to a cheaper loan.

Second, we test the mechanism behind the choice dynamics. On the one hand, we expect that making repayments on 
the flat plan would be reported as a greater burden when the flat plan is offered alongside a steep plan than when it is not. This is because we expect that the evaluation of the flat plan systematically depends on the other available options. On the other hand, we predict that the difference between the attention assigned to getting the loan and its costs would be smaller when the steep plan is offered than when it is not offered. This is because in the presence of the steep plan, consumers would attend to obtaining the loan and making repayments in a more balanced manner.

\section{Methods}

In both studies, participants made a hypothetical loan decision about whether to finance a car (Study 1) or a laptop purchase (Study 2) from a loan and if so, under which of the offered plans. Both studies were designed to test behavioral predictions about choice dynamics in the presence of the steep plan. In Study 1, we tested whether the preference for the flat plan decreases in the presence of the steep plan compared to when the flat plan is offered alone or alongside the slight plan and whether participants shift their preferences from borrowing under the flat plan to not borrowing. In this study, we used a car loan scenario because, after a home, a car is the largest financial asset that an individual typically owns (Larrimore et al. 2014). Car loans seem to attract people who are vulnerable and low-income people (Montezemolo 2012; Collins et al. 2017) which is worrisome and calls for interventions to mitigate harmful loan consumption (Ritholtz 2016).

In Study 2, we used a laptop loan scenario because over $86 \%$ of households in the United States (US) own a laptop or a desktop computer, and access to computers has become increasingly important in conducting day-to-day business (Ryan and Lewis 2017). On the one hand, we aimed to test the generalizability of Study 1's results on another durable good. On the other hand, we included questions examining the underlying mechanisms of the choice dynamics. We tested whether the presence of the steep plan alongside the flat plan causes the flat plan to be perceived as a greater burden and whether it causes subjects to redirect attention from obtaining the good toward making repayments on it. Furthermore, we asked subjects to indicate the likelihood that they would purchase a laptop or a desktop in the next 12 months and the likelihood that they would finance this purchase from a loan. This question enabled us to control for the real-life motivation to make a similar purchase in the near future, and the likelihood that this purchase would be financed by a loan.
In both experiments, the choice elicitation procedure was not incentive compatible but instead, the participants were paid a flat fee of USD 0.5 for completion.

\section{Design of the two studies}

Both studies were between-subject setups deploying a twoby-two factorial design with one structurally empty cell, yielding three conditions. The two factors were "extended set" and "salient repayment," and each had two levels. The factor "extended set" refers to whether a third option was present in addition to the original choice set of not borrowing or borrowing under a flat plan. The factor "salient repayment" refers to whether the added third option includes salient repayments or not. These combinations led to the following three conditions. In the flat condition, subjects choose between not borrowing or borrowing under the flat plan. In the slight condition, subjects choose between not borrowing, borrowing under the flat plan, or borrowing under the slight plan. Recall that this condition was necessary to control for increasing the cardinality of the choice set. In the steep condition, subjects choose between not borrowing, borrowing under the flat plan, or borrowing under the steep plan.

\section{The procedure of the two studies}

In both studies, participants were recruited from Amazon MTurk services. Amazon MTurk is a marketplace where people (i.e., MTurk workers) register to perform diverse, computer-based tasks (e.g., surveys, psychological or economic experiments, object rating, image labeling) in exchange for remuneration. In both studies, participants received a USD 0.5 completion fee, a typical payment on MTurk for a $10-15$ minutes long survey. The hourly wage on MTurk is between USD 3.75 and USD 5 for completing a survey task. When the MTurk worker completes a task, s/ he provides her/his completion code, and if the requester accepts her/his work s/he is paid. For more details on MTurk services, see www.mturk.com.

Using MTurk samples to obtain reliable quality data has been a widespread practice in psychology and social sciences. After reviewing the data quality of the MTurk samples, Buhrmester et al. (2011) report that MTurk samples are as good as lab samples but much cheaper.

The complete experimental materials for both studies are presented in Appendix B.

\section{Study 1}

After answering questions on demographics and prior loan experience(s), participants were presented a vignette describing their need for a new car and how, after some 
Please read this story very carefully.

Imagine that you want to purchase a car. After a long and careful selection, you have found a car that perfectly fits your needs and goals. However, you are $\$ 10,000$ short and are thus considering taking out a loan for this amount.

You live in a town in the US, you are married, your spouse also makes money and you are raising two school-aged children. You are earning $\$ 45,000$ per year before tax (which gives you approximately $\$ 3,750$ per month before tax) and your spouse makes approximately three-fourths (i.e., $75 \%$ ) of your income. You always file your taxes jointly with your spouse and both of your jobs are secure, at least for the next couple of years.

You research potentially interesting loans on the Internet. It seems that you are eligible to take out $\$ 10,000$. You can get this loan at a $6 \%$ yearly interest rate. You also learn from the web that the banks would give you $6 \%$ yearly, nontaxable interest for your money deposits. Moreover, there is no inflation in your country.

The dealership where you are considering buying the car has a financing department that is offering you the $\$ 10,000$ loan with a $6 \%$ yearly interest rate. Only in slight and steep conditions: This bank offers you a choice between two repayment plans. The two plans are identical in how much you end up paying for the loan and also in how much profit the bank makes on them.

They offer you to finance the car under a / The first plan is called the 'fixed-installments plan' because you would have to pay the same amount every month for the entire duration. In this flat plan, you would pay $\$ 860$ a month from the day you took out the loan and would repeat this payment on the same day of every month for the next 12 months.

Only in slight and steep conditions: The second plan is called the 'decreasing-installments plan' because you would have to pay a greater amount at the beginning and the size of the monthly payment would decrease over time. In this decreasing plan, you would pay the first installment a month from the day you took out the loan and would repeat this payment on the same day of every month for the next 12 months.

The financial department also informs you about the procedure.

On the day you sign the contract, they would pay $\$ 10,000$ towards your purchase of the selected car, and you then commit to paying the monthly installments on the same day of each month for the next 12 months. For a better understanding, they show you the following chart detailing what would happen in the following 12 months if you took out one of the loan plans (or if you did not take out the loan).

Fig. 1 Vignette presented in Study 1. Note: Condition-specific texts are italicized

research, they found the appropriate one and are now offered the choice of financing the purchase with a loan. The exact text of vignettes used in Study 1 is presented in Fig. 1.

Next, we quizzed participants on their understanding of the task and their recall of the vignette's details.

They were presented with the options corresponding to their respective conditions. Those opting not to borrow finished and received their payment. Those who opted to borrow in the slight and steep conditions indicated their preferred plan. Next, in all conditions, the participants rated the burden of repayment under each plan they were presented. Finally, these participants also finished the study and were paid.

\section{Study 2}

The experimental flow was similar to that of Study 1, with the good considered being instead a laptop computer, and the following four additions. First, after the questions on subjects' prior loan experiences, they were asked to indicate the minimum likelihood (on a $0 \%$ to $100 \%$ scale) that they would purchase a laptop in the upcoming 12 months and the minimum likelihood (on a $0 \%$ to $100 \%$ scale) that they would take out a loan to finance that purchase. Second, in the slight and steep conditions, they were explicitly told that the two offered loan plans (flat plan and slight in the slight condition and flat plan and steep plan in steep condition) were equivalent in how much they would repay in total, in their annual interest rates, and all the involved costs. Third, everyone (vs. only those opting to borrow as in Study 1) was asked to rate the burden of making repayments on every loan plan presented in their condition. Fourth, at the end of the experiment, they were asked to rate how much attention they paid to getting the laptop and to making repayments when they made their choices. 
Table 1 Monthly nominal installments and their present values(in parentheses) for each plan as used in Studies 1 and 2

\begin{tabular}{|c|c|c|c|c|c|c|}
\hline \multirow[t]{2}{*}{ Month } & \multicolumn{3}{|l|}{ Study 1} & \multicolumn{3}{|l|}{ Study 2} \\
\hline & Flat plan $(\$)$ & Slight plan (\$) & Steep plan $(\$)$ & Flat plan (\$) & Slight plan (\$) & Steep plan (\$) \\
\hline $1 \mathrm{st}$ & $\begin{array}{l}860 \\
(855.53)\end{array}$ & $\begin{array}{l}960 \\
(955.35)\end{array}$ & $\begin{array}{l}1300 \\
(1293.7)\end{array}$ & $\begin{array}{l}215.50 \\
(213.00)\end{array}$ & $\begin{array}{l}237.50 \\
(234.75)\end{array}$ & $\begin{array}{l}321.50 \\
(317.78)\end{array}$ \\
\hline 2nd & $\begin{array}{l}860 \\
(851.69)\end{array}$ & $\begin{array}{l}940 \\
(930.92)\end{array}$ & $\begin{array}{l}1220 \\
(1208.21)\end{array}$ & $\begin{array}{l}215.50 \\
(210.54)\end{array}$ & $\begin{array}{l}233.50 \\
(228.12)\end{array}$ & $\begin{array}{l}298.50 \\
(291.63)\end{array}$ \\
\hline $3 \mathrm{rd}$ & $\begin{array}{l}860 \\
(847.56)\end{array}$ & $\begin{array}{l}920 \\
(906.7)\end{array}$ & $\begin{array}{l}1140 \\
(1123.51)\end{array}$ & $\begin{array}{l}215.50 \\
(208.10)\end{array}$ & $\begin{array}{l}229.50 \\
(221.62)\end{array}$ & $\begin{array}{l}277.50 \\
(267.97)\end{array}$ \\
\hline 4 th & $\begin{array}{l}860 \\
(843.46)\end{array}$ & $\begin{array}{l}900 \\
(882.69)\end{array}$ & $\begin{array}{l}1060 \\
(1039.61)\end{array}$ & $\begin{array}{l}215.50 \\
(205.69)\end{array}$ & $\begin{array}{l}225.50 \\
(215.24)\end{array}$ & $\begin{array}{l}260.50 \\
(248.64)\end{array}$ \\
\hline 5 th & $\begin{array}{l}860 \\
(839.37)\end{array}$ & $\begin{array}{l}880 \\
(858.89)\end{array}$ & $\begin{array}{l}980 \\
(956.49)\end{array}$ & $\begin{array}{l}215.50 \\
(203.31)\end{array}$ & $\begin{array}{l}221.50 \\
(208.97)\end{array}$ & $\begin{array}{l}241.50 \\
(227.84)\end{array}$ \\
\hline 6th & $\begin{array}{l}860 \\
(835.31)\end{array}$ & $\begin{array}{l}860 \\
(835.31)\end{array}$ & $\begin{array}{l}900 \\
(874.16)\end{array}$ & $\begin{array}{l}215.50 \\
(200.95)\end{array}$ & $\begin{array}{l}217.50 \\
(202.82)\end{array}$ & $\begin{array}{l}222.50 \\
(207.48)\end{array}$ \\
\hline 7 th & $\begin{array}{l}860 \\
(831.26)\end{array}$ & $\begin{array}{l}840 \\
(811.93)\end{array}$ & $\begin{array}{l}810 \\
(782.93)\end{array}$ & $\begin{array}{l}215.50 \\
(198.63)\end{array}$ & $\begin{array}{l}213.50 \\
(196.78)\end{array}$ & $\begin{array}{l}203.50 \\
(187.57)\end{array}$ \\
\hline 8 th & $\begin{array}{l}860 \\
(827.23)\end{array}$ & $\begin{array}{l}830 \\
(798.38)\end{array}$ & $\begin{array}{l}730 \\
(702.19)\end{array}$ & $\begin{array}{l}215.50 \\
(196.33)\end{array}$ & $\begin{array}{l}208.50 \\
(189.95)\end{array}$ & $\begin{array}{l}184.50 \\
(168.09)\end{array}$ \\
\hline 9th & $\begin{array}{l}860 \\
(823.23)\end{array}$ & $\begin{array}{l}820 \\
(784.94)\end{array}$ & $\begin{array}{l}650 \\
(622.21)\end{array}$ & $\begin{array}{l}215.50 \\
(194.05)\end{array}$ & $\begin{array}{l}205.50 \\
(185.05)\end{array}$ & $\begin{array}{l}165.50 \\
(149.03)\end{array}$ \\
\hline 10th & $\begin{array}{l}860 \\
(819.24)\end{array}$ & $\begin{array}{l}800 \\
(762.08)\end{array}$ & $\begin{array}{l}570 \\
(542.98)\end{array}$ & $\begin{array}{l}215.50 \\
(191.81)\end{array}$ & $\begin{array}{l}200.50 \\
(178.46)\end{array}$ & $\begin{array}{l}145.50 \\
(129.50)\end{array}$ \\
\hline 11 th & $\begin{array}{l}860 \\
(815.27)\end{array}$ & $\begin{array}{l}788 \\
(747.01)\end{array}$ & $\begin{array}{l}490 \\
(464.51)\end{array}$ & $\begin{array}{l}215.50 \\
(189.59)\end{array}$ & $\begin{array}{l}195.50 \\
(171.99)\end{array}$ & $\begin{array}{l}125.50 \\
(110.41)\end{array}$ \\
\hline 12 th & $\begin{array}{l}860 \\
(811.32)\end{array}$ & $\begin{array}{l}770 \\
(726.42)\end{array}$ & $\begin{array}{l}414 \\
(390.57)\end{array}$ & $\begin{array}{l}215.50 \\
(187.39)\end{array}$ & $\begin{array}{l}190.50 \\
(165.65)\end{array}$ & $\begin{array}{l}107.50 \\
(93.48)\end{array}$ \\
\hline Sum & $\begin{array}{l}10,320 \\
(10,000.77)\end{array}$ & $\begin{array}{l}10,308 \\
(10,000.60)\end{array}$ & $\begin{array}{l}10,264 \\
(10,001.07)\end{array}$ & $\begin{array}{l}2586.00 \\
(2399.39)\end{array}$ & $\begin{array}{l}2579.00 \\
(2399.40)\end{array}$ & $\begin{array}{l}2554.00 \\
(2399.41)\end{array}$ \\
\hline
\end{tabular}

Note: Only nominal values were presented to participants

\section{Experimental materials for the loan decision in both studies}

In both experiments, we intended to facilitate attribute-wise processing when subjects were presented with the loan offers. Thus, the corresponding options were presented side by side for each condition so that subjects could treat monthly payments as attribute values and compare the options based on these values.

In both studies, we calculated the plans' nominal installments and respective present values (calculated by the given $6 \%$ and 15\% annual interest rates in Studies 1 and 2, respectively) by following Berk and DeMarzo (2014) and determined the present $\sum_{i=1}^{T}=\frac{x_{i}}{(1+r)^{i}}$ values, where $x_{i}$ is the $i$ th period's installment and $r$ is the interest rate. The left panel of Table 1 summarizes the nominal and present values for each month used in Study 1, and the right panel summarizes those for Study 2.

Table 1 also shows that within each study, the sums of the monthly installments' present values were the same (with only a few cents difference) across conditions. In the flat plans of both studies, the nominal installment sizes were the same each month. In the slight plans of both studies, the decrease in subsequent monthly installments was small, with nominal installments differing only slightly from those in the flat plan. In the steep plan of both studies, the subsequent monthly installments differed significantly from those of the flat plan. They started at a much greater value and ended much lower than the corresponding monthly installments in the flat plan.

\section{Participants}

\section{Study 1}

Two hundred seventy-six US citizens started the study. Forty-one were excluded because of attrition or failing the quiz (12 and 29 participants, respectively). Of the remaining 235 participants, there were 72 in the flat, 80 in the slight, and 83 in the steep conditions.

Based on the first row of the top panel of Table 2, the mean age differs between the three conditions. Games-Howell post hoc comparisons show that participants are older in the slight than in the steep condition, $p \leq 0.01$, and there is 
Table 2 Demographic characteristics of participants in Studies 1 and 2

\begin{tabular}{|c|c|c|c|c|}
\hline & \multicolumn{4}{|l|}{ Study 1} \\
\hline & $\begin{array}{l}\text { Flat condition } \\
n=72\end{array}$ & $\begin{array}{l}\text { Slight condition } \\
n=80\end{array}$ & $\begin{array}{l}\text { Steep condition } \\
n=83\end{array}$ & Test of statistical differences \\
\hline Mean (SD) age & $\begin{array}{l}34.14 \\
(11.53)\end{array}$ & $\begin{array}{l}38.71 \\
(12.80)\end{array}$ & $\begin{array}{l}32.51 \\
(10.25)\end{array}$ & $W(2,151)^{1}=5.89^{* *}$ \\
\hline Male N (\%) & $\begin{array}{l}37 \\
(51.4 \%)\end{array}$ & $\begin{array}{l}48 \\
(60.0 \%)\end{array}$ & $\begin{array}{l}47 \\
(56.6 \%)\end{array}$ & $\chi^{2}(2, \mathrm{~N}=235)=1.15$ \\
\hline Median income & $<\$ 55,000$ gross per year & $\begin{array}{l}<\$ 55,000 \\
\text { gross per year }\end{array}$ & $<\$ 55,000$ gross per year & $\chi^{2}(6, \mathrm{~N}=235)=2.59$ \\
\hline \multirow[t]{3}{*}{ Minimum one prior loan $\mathrm{N}(\%)$} & $\begin{array}{l}61 \\
(84.7 \%)\end{array}$ & $\begin{array}{l}71 \\
(88.8 \%)\end{array}$ & $\begin{array}{l}66 \\
(79.5 \%)\end{array}$ & $\chi^{2}(2, \mathrm{~N}=235)=2.63$ \\
\hline & \multicolumn{4}{|l|}{ Study 2} \\
\hline & $\begin{array}{l}\text { Flat condition } \\
n=145\end{array}$ & $\begin{array}{l}\text { Slight condition } \\
n=161\end{array}$ & $\begin{array}{l}\text { Steep condition } \\
n=152\end{array}$ & Test of statistical differences \\
\hline Mean (SD) age & $\begin{array}{l}37.26 \\
(12.49)\end{array}$ & $\begin{array}{l}38.20 \\
(11.50)\end{array}$ & $\begin{array}{l}39.27 \\
(13.82)\end{array}$ & $F(2,455)=0.95$ \\
\hline Male N (\%) & $\begin{array}{l}76 \\
(52.4 \%)\end{array}$ & $\begin{array}{l}74 \\
(46.0 \%)\end{array}$ & $\begin{array}{l}81 \\
(53.3 \%)\end{array}$ & $\chi 2(2, \mathrm{~N}=458)=2.01$ \\
\hline Median income & $<\$ 55,000$ gross per year & $<\$ 55,000$ gross per year & $<\$ 55,000$ gross per year & $\chi 2(6, N=458)=9.10$ \\
\hline Minimum one prior loan N (\%) & $\begin{array}{l}119 \\
(82.1 \%)\end{array}$ & $\begin{array}{l}130 \\
(80.7 \%)\end{array}$ & $\begin{array}{l}113 \\
(74.3 \%)\end{array}$ & $\chi 2(2, \mathrm{~N}=458)=3.11$ \\
\hline $\begin{array}{l}\text { Mean (SD) minimum likeli- } \\
\text { hood of purchasing a laptop } \\
\text { in the next } 12 \text { months in real } \\
\text { life }\end{array}$ & $\begin{array}{l}48.39 \% \\
(30.67)\end{array}$ & $\begin{array}{l}47.70 \% \\
(30.46)\end{array}$ & $\begin{array}{l}46.52 \% \\
(32.65)\end{array}$ & $F(2,455)=0.14$ \\
\hline $\begin{array}{l}\text { Mean (SD) minimum likeli- } \\
\text { hood of financing a laptop } \\
\text { purchase from a loan in real } \\
\text { life }\end{array}$ & $\begin{array}{l}22.07 \% \\
(30.26)\end{array}$ & $\begin{array}{l}19.51 \% \\
(26.81)\end{array}$ & $\begin{array}{l}23.00 \% \\
(31.37)\end{array}$ & $F(2,455)=0.59$ \\
\hline
\end{tabular}

${ }^{1}$ We report Welch statistics to account for the unequal variances

$* * p \leq 0.01$

no age difference between the flat and the other two conditions. Additionally, neither gender (row two) nor income level (row three) differs between conditions. Similarly, most participants have taken out at least one loan in the past 20 years, and this does not differ between conditions (row four).

\section{Study 2}

Four hundred ninety-five US citizens started the study. Thirty-seven were excluded because of attrition. Of the remaining 458 participants, 145 are in the flat, 161 in the slight, and 152 in the steep conditions.

The first row of the lower panel of Table 2 shows that the mean age does not differ between conditions. Similarly, the gender and the income distributions are the same in the three conditions (rows two and three). From row four we observe that most participants report having taken out at least one loan in the past 20 years. From the fifth row, we observe that the mean self-reported minimum likelihood of purchasing a new laptop in the next 12 months does not differ across conditions, with an overall mean close to $50 \%$. Finally, from row six, we observe no difference in participants' reported likelihood of financing a laptop purchase from a loan, with an overall mean of approximately $20 \%$. In Appendix C, we present detailed descriptive results from both studies.

\section{Predictions}

In both experiments, we tested three behavioral predictions ( $\mathrm{H} 1, \mathrm{H} 2$, and $\mathrm{H} 3$ ) of which $\mathrm{H} 1$ and $\mathrm{H} 2$ were derived from the propositions presented in Appendix A. In Study 2, we further tested two, process-oriented predictions ( $\mathrm{H} 4$ and $\mathrm{H} 5)$ about the underlying mechanisms of the observed preference shifts predicted in $\mathrm{H} 2$ and $\mathrm{H} 3$.

H1 There would be no difference between the preference for the slight and steep plans. Confirming $\mathrm{H} 1$ is a prerequisite to addressing $\mathrm{H} 2$ and $\mathrm{H} 3$. 


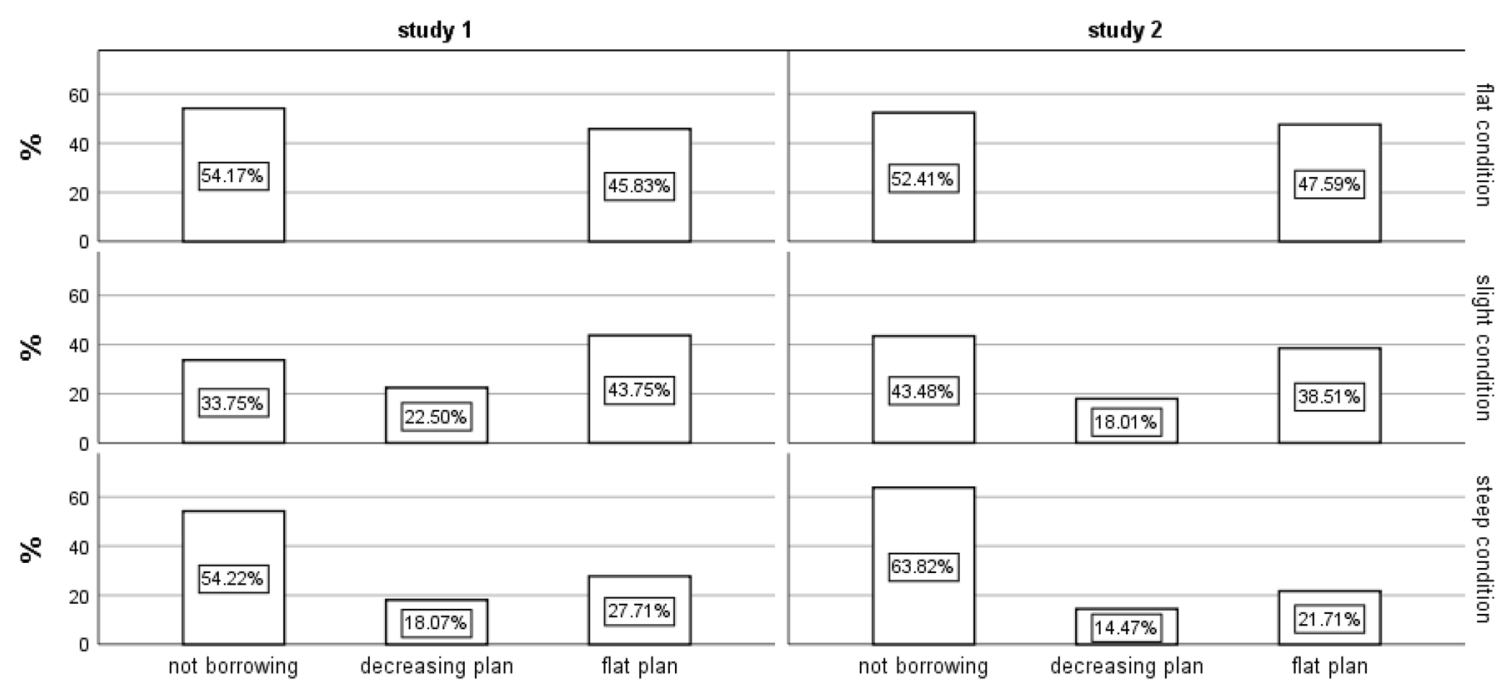

Fig. 2 The distribution of choices in the three conditions in Study 1 (left panel) and Study 2 (right panel).

Note: Percent (\%) indicates the proportion of participants choosing each alternative in each condition in Studies 1 (left panel) and 2 (right panel)

Table 3 Summary of binary logistic regressions of decreasing plan preferred under different model specifications in Studies 1 and 2

\begin{tabular}{llll}
\hline & $\begin{array}{l}\text { Study 1 } \\
\text { Model I }\end{array}$ & Study 2 & Model I \\
\cline { 3 - 4 } & $-1.24(0.27)^{* * *}$ & $-1.52(0.21)^{* * *}$ & $-1.75(0.32)^{* * *}$ \\
Intercept & $-0.27(0.39)$ & $-0.26(0.31)$ & $-0.26(0.31)$ \\
Salient repayment =1 & & & $0.01(0.01)$ \\
RealLifeLaptopPurchase & & & $0.00(0.01)$ \\
RealLifeLaptopLoan & 0.49 n.s & 0.72 n.s & 1.63 n.s \\
LR $\chi^{2}$ & 1 & 1 & 3 \\
Df & 163 & 313 & 313 \\
$\mathrm{~N}$ & & & \\
\hline
\end{tabular}

Notes: Dependent variable: Decreasing plan preferred dummy variable

The sample is restricted to the slight and steep conditions in both studies Coefficients are on the logit scale, and standard errors are in parentheses $* * * p \leq 0.001$

H2 The flat plan would be less preferred in the steep condition than in the slight and the flat conditions.

H3 In the steep condition, not borrowing would be more preferred than the flat plan, while no such preference would exist in the flat and slight conditions.

H4 The perceived mean burden of making repayments under the flat plan would be greater in the steep than in the flat and slight conditions.

H5 The mean difference between attention to getting the loan and attention to the repayments would be greater in the steep condition than in the flat and slight conditions.

\section{Results}

We first address the three behavioral predictions and then move to test the two process-oriented hypotheses.
Figure 2 describes the distribution of choices in the three conditions in the two studies. We find that the distribution of choices differs in both studies, $\chi^{2}(4, N=235)=23.87$, $p \leq 0.001$ in Study 1 , and $\chi^{2}(2, N=458)=45.00, p \leq 0.001$ in Study 2. Choice distributions, however, do not differ between the two studies, $\chi^{2}(2, N=693)=2.47$, n.s..

To test H1, we restrict the sample in both studies to the slight and steep conditions and create a decreasing plan preferred dummy variable. The value of this variable is 1 if either decreasing plan is preferred (i.e., the slight plan in the slight condition or steep plan in the steep condition) and 0 otherwise. In Study 1 (Model I of Table 3's left panel), we find that the slight and the steep plans are not differently preferred between the slight and steep conditions. In the two right columns of Model I and II, including the results from Study 3, we find the same pattern. Note that these results are robust after controlling for gender, income level, and 
Table 4 Summary of binary logistic regressions of the flat plan preferred under different model specifications in Studies 1 and 2. Dependent variable: flat plan preferred dummy variable

\begin{tabular}{llll}
\hline & Study 1 & \multicolumn{2}{l}{ Study 2 } \\
\cline { 3 - 4 } & Model I & Model I & Model II \\
\hline Intercept & $0.17(0.24)$ & $-0.10(0.17)$ & $-0.46(0.24)^{*}$ \\
Extended set =1 & $-0.08(0.33)$ & $-0.37(0.23)$ & $-0.35(0.24)$ \\
Salient repayment $=1$ & $-0.71(0.33)^{*}$ & $-0.82(0.26)^{* * *}$ & $-0.94(0.27)^{* * *}$ \\
RealLifeLaptopPurchase & & & $0.00(0.004)$ \\
RealLifeLaptopLoan & & & $0.02(0.004)^{* * *}$ \\
LR $\chi^{2}$ & $6.79 *$ & $23.16^{* * *}$ & $50.07^{* * *}$ \\
Df & 2 & 2 & 4 \\
$\mathrm{~N}$ & 235 & 458 & 458 \\
\hline
\end{tabular}

Notes: Coefficients are on the logit scale, and standard errors are in parentheses

$* * * p \leq 0.001 ; * * p \leq 0.01$ having at least one loan in real life. Additionally, however, confirming that participants did consider the decreasing plans in their respective conditions, we find that in Study 2, participants rated making repayments on the steep plan as a greater burden (Mean $(S D)_{\text {steep plan }}=2.72(0.92)$ ) than making repayments on the slight plan (Mean $(S D)_{\text {slight plan }}=2.27$ $(0.79)), W(1,298)=21.41, p \leq 0.001 .^{3}$

Confirming $\mathrm{H} 1$ allows us to address $\mathrm{H} 2$, where we again include subjects from all three conditions. We create a flat plan preferred dummy variable which takes the value of 1 if the flat plan is chosen and 0 if not borrowing or borrowing under the decreasing plan are selected. Next, we regress (binary logistic regression) the flat plan preferred variable on the two experimental factors coded as dummy variables. The extended set variable is coded 1 when the choice set includes three options (as in slight and steep conditions) and 0 when it includes only two options (as in the flat condition). The salient repayment variable is coded 1 when the choice set includes the steep plan (i.e., steep condition) to highlight the salience of the repayments, and 0 otherwise (i.e., flat and slight conditions). Recall that the extended set $\mathrm{X}$ salient repayment interaction is meaningless because of the structurally empty cell.

In Model I presented in the left panel of Table 4, we find that in Study 1, the presence of the salient repayment (i.e., steep plan) decreases the likelihood of choosing the flat plan over the combined likelihood of not borrowing and choosing the steep plan. This result is robust after controlling for income level, gender, and having at least one loan in real life.

In the right panel of Table 4, in Model I, we observe similar patterns in Study 2. The presence of the steep plan (i.e., salient repayment term) decreases the likelihood of opting for the flat plan. From Model II, we learn that the same result holds after controlling for subjects' reported minimum

\footnotetext{
${ }^{3}$ Only in Study 2 was everyone asked to rate the burden of making repayments under each plan.
}

likelihood of purchasing a laptop in real- life in the next 12 months (variable labeled as realLifeLaptopPurchase) and the reported minimum likelihood of taking out a loan for this purchase (variable labeled as realLifeLaptopLoan). As can one see from this model, a higher likelihood of taking out a loan to purchase a laptop is associated with an increase in the likelihood of selecting the flat plan over not borrowing or choosing the decreasing plans, although by a very slight amount. Again, these results are robust after controlling for income level, gender, and having at least one real-life loan. In summary, we find support for H2: the preference for the flat plan over not borrowing or choosing the decreasing plan is lower in the presence of the steep plan.

To address H3, we perform a series of multinomial logistic regressions of the choice variable and present results in Table 5. In the flat condition, the choice variable has two levels: not borrowing or borrowing under the flat plan. In the slight and steep conditions, a third level is added: borrowing under the slight plan as in the slight condition, or borrowing under the steep plan as in the steep condition. With multinomial logistic regression, under different model specifications, we model the probability difference of choosing not to borrow and choosing the flat plan (i.e., the reference category is choosing the flat plan). Setting the reference category to choosing the flat plan allows us to examine our key research interest: how does preference for the flat plan change as a result of adding the steep plan, provided that $\mathrm{H} 1$ is confirmed.

Consulting with the first column of the left panel of Table 5 (results from Study 1), we find a nonsignificant intercept. This implies that in the flat condition, not borrowing and choosing the flat plan are equally preferred. We also learn that extending the choice set with the slight plan (extended set $=1$ ) makes no difference: not borrowing and choosing the flat plan are equally likely in the slight condition. However, adding the salient repayment term (i.e., adding the steep plan) increases the likelihood of choosing not to borrow over the flat plan. 
Table 5 Summary of multinomial logistic regressions of choice under different model specifications in Studies 1 and 2. Dependent variable: choice $=$ not borrowing

\begin{tabular}{llll}
\hline & $\begin{array}{l}\text { Study 1 } \\
\text { Model I }\end{array}$ & \multicolumn{2}{l}{ Study 2 } \\
\cline { 4 - 4 } & Model I & Model II \\
\hline Intercept & $0.17(0.24)$ & $0.10(0.17)$ & $0.53(0.24) *$ \\
Extended set $=1$ & $-0.43(0.35)$ & $0.03(0.24)$ & $-0.02(0.25)$ \\
Salient repayment $=1$ & $0.93(0.36) * *$ & $0.96(0.27) * * *$ & $1.10(0.28) * * *$ \\
RealLifeLaptopPurchase & & & $0.00(0.004)$ \\
RealLifeLaptopLoan & & & $-0.02(0.004) * * *$ \\
LR $\chi^{2}$ & $33.76 * * *$ & $60.76 * * *$ & $91.58 * * *$ \\
Df & 4 & 4 & 8 \\
$\mathrm{~N}$ & 235 & 458 & 458 \\
\hline
\end{tabular}

Notes: Reference category is flat plan preferred. Coefficients are on the logit scale, and standard errors are in parentheses

$* * * p \leq 0.001 ; * * p \leq 0.01 ; * p \leq 0.05$

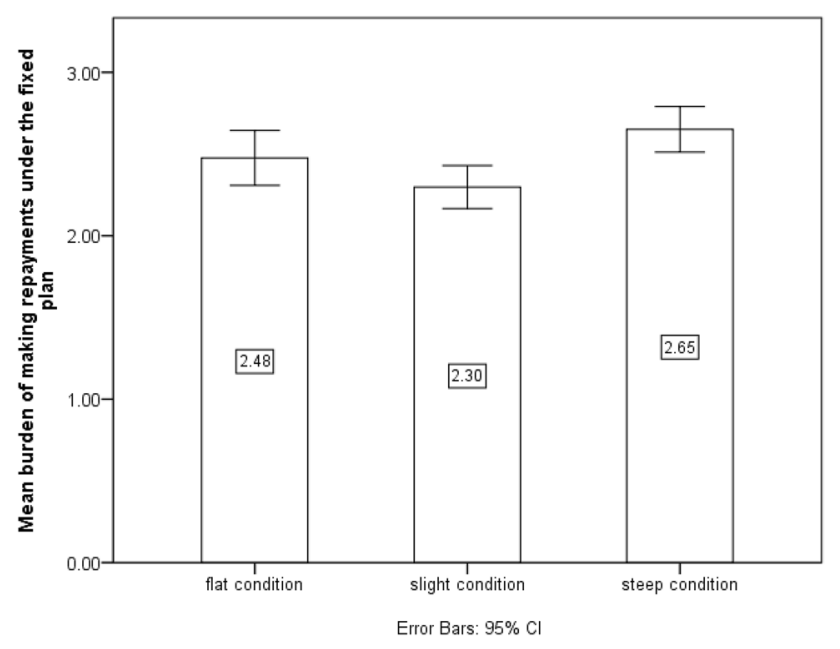

Fig. 3 Mean burden ratings of making repayments under the flat plan in the three conditions of Study 2.

Note: Responses are anchored on a four-level Likert scale: 1 -not a burden at all, 2-a little bit of a burden, 3-moderate burden, 4great burden

In the two right columns of Table 5, we present results from Study 2. In Model I, we find results similar to those in Model I of Study 1: the flat plan and not borrowing are equally likely to be selected in the flat and in the slight conditions, while not borrowing is more likely than choosing the flat plan in the steep condition. From the significant intercept in Model II, however, we learn that after controlling for the realLifeLaptopPurchase and realLifeLaptopLoan terms, in the flat condition, the likelihood of not borrowing over choosing the flat plan is higher. We also learn that in the steep condition (salient repayment term $=1$ ), not borrowing is still more likely to be preferred over the flat plan even after controlling for the real-life plan of purchasing a laptop and taking out a loan for this purchase. These results are robust after controlling for income level, gender, and having at least one real-life loan.

To test $\mathrm{H} 4$ and H5, we restrict the sample to Study 2. As one can see from Fig. 3, the burden of making repayment under the flat plan is rated differently between the three conditions, $W(2,298)=6.63, p \leq 0.01$.

To address H4, we perform a series of linear regressions of burden ratings of the flat plan on the experimental factors. Model I of Table 6 reports that when salient repayment is present, the mean burden of repayment under the flat plan is increased compared to when it is absent, and the effect of the extended set is zero. We add the income level in Model II and find that as income level increases, making repayments under the flat plan is considered less of a burden. From Model III, we find the same results and also that an increase in the likelihood of financing a laptop purchase in real life decreases these ratings. In other words, individuals planning to take out a loan in real life report on average a lower perceived burden of the flat plan, although by a very low amount.

To test H5, we first create an attentionDifference variable by taking the difference between reported attention to repaying the loan versus attention to obtaining the loan when making the choice (the $i$ th participant response on paying attention to repaying the loan minus the $i$ th participant response on paying attention to obtaining the loan). From Fig. 4, one can see that these means differ between the three conditions, $W(2,298)=5.91, p \leq 0.01$, and that only in the steep condition does this mean differ from zero (95\% CIs do not include zero).

To address H5, we regress the attentionDifference variable on the usual model specifications. From Model I of Table 7, we observe that when salient repayment is present, the attentionDifference increases, whereas there is no effect of the extended set. From Model II, we see that the same 
Table 6 Summary of linear regressions of the flat plan's burden in Study 2 under different model specifications

\begin{tabular}{llll}
\hline & Model I & Model II & Model III \\
\hline Intercept & $2.48(0.07)^{* * *}$ & $2.99(0.12)^{* * *}$ & $3.08(1.29)^{* * *}$ \\
Extended set =1 & $-0.18(0.10)$ & $-0.17(0.10)$ & $-0.18(0.10)$ \\
Salient repayment =1 & $0.35(0.10)^{* * *}$ & $0.30(0.10)^{* *}$ & $0.32(0.10)^{* * *}$ \\
Income level & & $-0.24(0.04)^{* * *}$ & $-0.24(0.04)^{* * *}$ \\
RealLifeLaptopPurchase & & & $0.00(0.001)$ \\
RealLifeLaptopLoan & & & $-0.004(0.001)^{* *}$ \\
LR $\chi^{2}$ & $11.66^{* *}$ & $40.38 * * *$ & $48.76 * * *$ \\
Df & 2 & 3 & 5 \\
$\mathrm{~N}$ & 458 & 458 & 458 \\
\hline
\end{tabular}

Notes: Dependent variable: burden of making repayments under the flat plan

Standard errors are in parentheses

$* * * p \leq 0.001 ; * * p \leq 0.01 ; * p \leq 0.05$ effect of salient repayment is present after we control for subjects' real-life likelihood of purchasing a laptop and financing this by using a loan, and these latter two individual characteristics are not associated with this difference. Note that these results are robust after controlling for income level, gender, and having at least one real-life loan.

\section{Discussion}

In two studies on hypothetical loan decisions, we demonstrated that increasing attention to a loan's costs by offering a steep plan alters preferences for borrowing under the flat plan such that people shift their preferences toward not

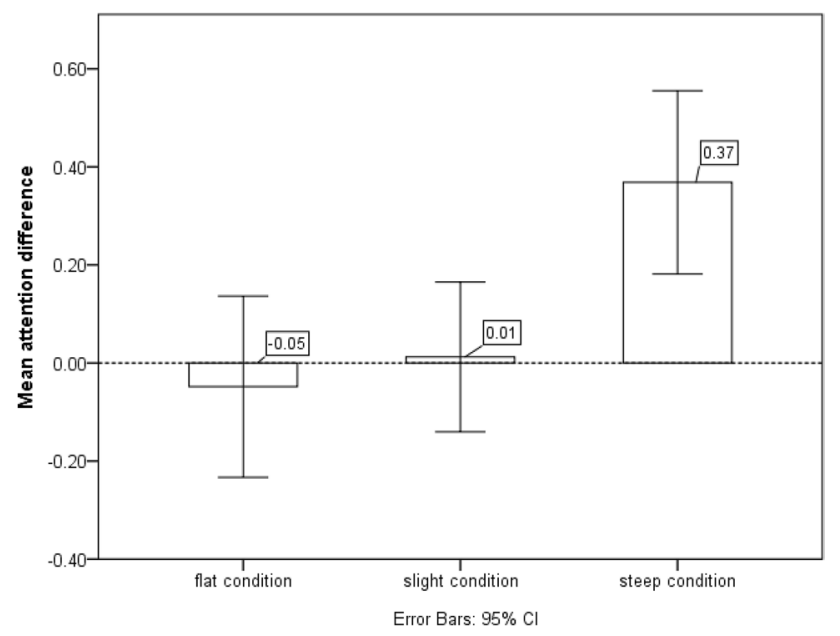

Fig. 4 Mean differences between attending to making repayments and obtaining the loan in the three conditions of Study 2.

Notes: The attentionDifference variable ranges from -4 to 4 . It is the difference between individual responses to "attention paid to repaying the loan" and "to obtain the loan" (repaying minus obtaining). Both questions were rated on a four-level Likert scale: 1-absolutely agree, 2-agree, 3-disagree, and 4-absolutely disagree. The dotted reference line is at mean $=0$. A larger number indicates that more attention is paid to making repayments than to obtaining the loan borrowing from opting for the flat plan. Specifically, we demonstrated a simple method by which focusing illusion can be decreased in loan decisions without restricting the decision-makers' choice set or forbidding them from choosing any options. Our results provide empirical support for BND's conjecture that offering a steep plan alongside the flat plan results in shifting consumers' attention toward the remote costs of the loan and prompts them to internalize the underappreciated, delayed costs of borrowing. We propose that this simple, cheap intervention could be used in settings where consumers are contemplating borrowing to purchase a durable good but are at risk of succumbing to focusing illusion when signing up for a loan.

The crux of the intervention is to extend the usual set of loan offers with an option that includes salient repayments, which sobers consumers who might be lured toward borrowing. Our key result is that when the choice triplet included the steep plan, preference for the flat plan decreased compared to when the steep plan was absent, while preference for the slight and steep decreasing plans did not change. In

Table 7 Summary of linear regressions of the difference between paying attention to making repayments and obtaining the good (attentionDifference) in Study 2

\begin{tabular}{lll}
\hline & Model I & Model II \\
\hline Intercept & $-0.05(0.09)$ & $0.02(0.12)$ \\
Extended set $=1$ & $0.06(0.12)$ & $0.05(0.12)$ \\
Salient repayment $=1$ & $0.36(0.12)^{* *}$ & $0.37(0.12)^{* *}$ \\
RealLifeLaptopPurchase & & $0.00(0.002)$ \\
RealLifeLaptopLoan & & $-0.003(0.002)$ \\
LR $\chi^{2}$ & $12.76^{* *}$ & $14.97^{* *}$ \\
Df & 2 & 4 \\
$\mathrm{~N}$ & 458 & 458 \\
\hline
\end{tabular}

Notes: Dependent variable: attentionDifference

Standard errors are in parentheses

$* * * p \leq 0.001 ; * * p \leq 0.01$ 
particular, in the presence of the steep plan, preference for the flat plan shifted toward not borrowing.

Examining the underlying mechanisms of this preference shift, we found that when the flat plan is paired with the steep plan, the perceived burden of making repayments on the flat plan is increased. It seems that the salient repayments of the steep plan directed attention toward the flat plan's repayment-exactly in line with the BND argument. Additionally, when the steep plan was present, participants reported shifting their attention from obtaining the loan to making repayments-again, as assumed by BND.

To the best of our knowledge, in real life, multiple repayment options are only presented in the event of offering federal student loans. These include the "plain-vanilla" option which corresponds to our flat plan, a plan in which installments are increasing over time, and a third plan where the installments' sizes depend on the borrowers' income and marital status. In the current lending practices, neither the presentation of student loans nor the presentation of any loans entertains the idea of directing the consumers' attention to the loan costs. Yet there is, despite the mandatory loan counseling required by the US Department of Education (USDOE), an increasing rate of student loan delinquency, and the counseling seems to be associated with increased complexity and hence confusion (e.g., Akers and Chingos 2014). As we have demonstrated, presenting an option with salient repayments could be a simple practice to mitigate the likelihood of premature loan consumption without increasing the existing complexity. The added steep plan could give some form of an intuitive grasp for potential borrowers on what it means to make monthly repayments, even in the event of choosing the flat plan.

\section{Limitations}

We acknowledge that our studies have limitations. First, if we could have elicited subjects' discount rates, we could have created tailor-made loan offers for subjects. In this way, we would have been able to observe how present bias interacted with our intervention. Nevertheless, this could have introduced a selection into our study and thus undermined its interpretability. Additionally, we had no means of determining whether the presence of the steep plan had deterred only high-risk borrowers from taking out the flat plan or everyone. Also, in our studies, subjects were paid a fixed fee so that their payoffs were not contingent upon their choices. Nevertheless, we conjecture that in a hypothetical setup, people make less conservative choices than in an incentive-compatible setting. We suspect, however, that if this were the case, our interventions would be even more efficient in real-life with real stakes. Another limitation of our design is having used a between-subject instead of a within-subject design, which may have been more suitable to address the proposed preference shift. With a within-subject design, however, the subjects, instead of revealing their true preferences, might have wanted to be seen as consistent, which could have undermined our treatment manipulations. Finally, we did not include information on the loan's total cost which is mandatory according to TILA. This information should be certainly added to the information sheet. We did, however, conform to TILA by giving information about the length of the repayment period and the annual percentage rate. Nevertheless, one should indeed examine how the added plans change the perception of complexity and the borrowing choices overall.

\section{Concluding remarks}

We conclude that if this intervention is confirmed in field settings, a policy may prescribe how to present loan offers to finance durable goods to potential consumers. Specifically, when multiple and equivalent loan plans are offered, the presentation should include a steep plan to counterbalance the salience of obtaining the loan by attracting attention to the repayments. In this manner, the utility maximized during the choice is more consistent with the utility realized after the transaction. Consequently, we may expect more prudent decisions on loans for durable goods, which protects consumers and decreases the negative societal and financial consequences of loan defaults.

Supplementary Information The online version contains supplementary material available at https://doi.org/10.1057/s41264-021-00124-x.

Acknowledgements This manuscript has been previously circulated under the title "Dampening focusing-illusion to protect borrowers". Linda Dezső received funding from the Back to Research Grant from the University of Vienna and the Hertha Firnberg Grant (\#T-1047-G27) from the Austrian Science Fund. Barna Bakó received funding from the Hungarian National Research, Development and Innovation Office (NKFI-132343). We are grateful to Cait Lamberton for her valuable suggestions on the Study 2 design and comments on the manuscript. Additionally, we would like to thank Lőrinc Szánthó for his research assistance.

Funding Open access funding provided by University of Vienna.

Data availability https://osf.io/9y5bv/?view_only=dc1df207c38b4c2 d8afc153288054101.

\section{Declarations}

Conflict of interest On behalf of all authors, the corresponding author states that there is no conflict of interest.

Open Access This article is licensed under a Creative Commons Attribution 4.0 International License, which permits use, sharing, adaptation, distribution and reproduction in any medium or format, as long as you give appropriate credit to the original author(s) and the source, provide a link to the Creative Commons licence, and indicate if changes were made. The images or other third party material in this article are included in the article's Creative Commons licence, unless indicated otherwise in a credit line to the material. If material is not included in 
the article's Creative Commons licence and your intended use is not permitted by statutory regulation or exceeds the permitted use, you will need to obtain permission directly from the copyright holder. To view a copy of this licence, visit http://creativecommons.org/licenses/by/4.0/.

\section{References}

Abaluck, J. 2011. What Would We Eat if We Knew More: The Implications of a Large-Scale Change in Nutrition Labeling, Working Paper, MIT. Available at: http://economics.stanford.edu/files/ Abaluck10_28.pdf.

Akers, B., and M. M. Chingos .2014. Is a student loan crisis on the horizon?. Brown Center on Education Policy at the Brookings Institution.

Bakó, B., G. Neszveda, and L. Dezsô. 2018. When irrelevant alternatives do matter: The effect of focusing on loan decisions. Theory and Decision 84: 123-141. https://doi.org/10.1007/ s11238-017-9641-9.

Berk, J., and P. DeMarzo. 2014. Corporate finance, 3rd ed. Boston: Prentice-Hall.

Brown, S., et al. 2005. Debt and financial expectations: An individualand household-level analysis. Economic Inquiry 43 (1): 100-120. https://doi.org/10.1093/ei/cbi008.

Buhrmester, M., T. Kwang, and S.D. Gosling. 2011. Amazon's mechanical turk: A new source of inexpensive, yet high-quality, data? Perspectives on Psychological Science 6 (1): 3-5. https:// doi.org/10.1177/1745691610393980.

Cai, C.W. (2020), Nudging the financial market? A review of the nudge theory. Account Finance, 60: 3341-3365. https://doi.org/10.1111/ acfi. 12471

Collins, J.M., L. Gjertson, and J. Sydnor. 2017. Incentives for loan repayments: evidence from a randomized field study. Journal of Consumer Affairs. https://doi.org/10.1111/joca.12142.

Cox, R., D. Brounen, and P. Neuteboom. 2015. Financial literacy, risk aversion and choice of mortgage type by households. Journal of Real Estate Finance and Economics 50 (1): 74-112. https://doi. org/10.1007/s11146-013-9453-9.

Dezső, L., and E. Kirchler. 2013. Loving you from your first cents and leaving you with our debts: Money management in the household. In Handbook of psychology of emotions: Recent theoretical perspectives and novel empirical findings, ed. C. Mohiyeddini, M. Eysenck, and S. Bauer, 141-168. New York: Nova Publisher.

Dezsô, L., and G. Loewenstein. 2012. Lenders' blind trust and borrowers' blind spots: A descriptive investigation of personal loans. Journal of Economic Psychology 33 (5): 996-1011. https://doi. org/10.1257/aer.98.1.534.

Dunn, E.W., T.D. Wilson, and D.T. Gilbert. 2003. Location, location, location: The misprediction of satisfaction in housing lotteries. Personality \& Social Psychology Bulletin 29 (11): 1421-32. https://doi.org/10.1177/0146167203256867.

Federal Reserve Bank of New York. 2020. Charge-off and delinquency rates on loans and leases at commercial banks. Available at: https://www.federalreserve.gov/releases/chargeoff/delallsa.htm.

Frederick, S., G. Loewenstein, and T. O'Donoghue. 2008. Time discounting and time preference : A critical review. Journal of Economic Literature 40 (2): 351-401.

Friztdixon, K., J. Hawkins, and M. P. Skiba. 2014. Dude, where's my car title? The law, behavior, and economics of title lending markets. University of Illinois Law Review, (4), pp. 1013-1058.

Getter, D.E. 2003. Contributing to the delinquency of borrowers. Journal of Consumer Affairs 37 (1): 86. https://doi.org/10.1111/j.17456606.2003.tb00441.x.
Hoelzl, E., B. Kamleitner, and E. Kirchler. 2011. Loan repayment plans as sequences of installments. Journal of Economic Psychology 32 (4): 621-631. https://doi.org/10.1016/j.joep.2011.02.002.

Hoelzl, E., M. Pollai, and B. Kamleitner. 2009. Experience, prediction and recollection of loan burden. Journal of Economic Psychology 30 (3): 446-454. https://doi.org/10.1016/j.joep.2008.11.001.

Hsee, C.K., et al. 1999. Preference reversals between joint and separate evaluations of options: A review and theoretical analysis. Psychological Bulletin 125 (5): 576-590. https://doi.org/10.1037// 0033-2909.125.5.576.

Hynes, R.M. 2004. Overoptimism and overborrowing. Brigham Young University Law Review 39 (1): 127-168.

Kahneman, D., et al. 2006. Would you be happier if you were richer? A focusing illusion. Science 312 (5782): 1908-1910. https://doi. org/10.1126/science.1129688.

Kamleitner, B., E. Hoelzl, and E. Kirchler. 2010. Experiencing costs and benefits of a loan transaction: The role of cost-benefit associations. Journal of Economic Psychology 31 (6): 1047-1056. https:// doi.org/10.1016/j.joep.2010.09.005.

Kamleitner, B., and E. Kirchler. 2006. Personal loan users' mental integration of payment and consumption. Marketing Letters 17 (4): 281-294. https://doi.org/10.1007/s11002-006-8521-9.

Kim, K.T., M.J. Wilmarth, and R. Henager. 2017. Poverty levels and debt indicators among low-income households before and after the great recession. Journal of Financial Counseling and Planning 28 (2): 196-212.

Kőszegi, B., and A. Szeidl. 2013. A model of focusing in economic choice. The Quarterly Journal of Economics 128 (1): 53-104. https://doi.org/10.1093/qje/qjs049.Advance.

Lacko, J.M., and J.M. Pappalardo. 2010. The failure and promise of mandated consumer mortgage disclosures: evidence from qualitative interviews and a controlled experiment with mortgage borrowers. American Economic Review 100 (2): 516-521.

Larrimore, J., S. Dodini, and L. Thomas. 2014. Report on the Economic Well-Being of U.S. Households in 2013. Available at: http:// www.federalreserve.gov/econresdata/2014-report-economic-wellbeing-us-households-201505.pdf.

Meier, S., and C. Sprenger. 2012. Present-biased preferences and credit card borrowing. Economics, American Economic Journal: Applied 2 (1): 193-210. https://doi.org/10.1257/app.2.1.193.

Montezemolo, S. 2012. The state of lending in america \& its impact on U.S. Households. Available at: www.responsiblelending.org.

Neszveda, G., and L. Dezső. 2012. A kvázi- és általánosított hiperbolikus diszkontálás hosszú távon. Szigma XLIII (3-4): 163-177.

Perry, V.G. 2008. Is ignorance bliss? Consumer accuracy in judgments about credit ratings. Journal of Consumer Affairs 42 (2): 189-205. https://doi.org/10.1111/j.1745-6606.2008.00104.x.

Perry, V.G., and P.M. Blumenthal. 2012. Understanding the fine print: The need for effective testing of mandatory mortgage loan disclosures. Journal of Public Policy \& Marketing 31 (2): 305-312. https://doi.org/10.1509/jppm.12.055.

Ritholtz, B. 2016. No, subprime auto loans are not like subprime mortgages. Bloomberg View. Available at: https://www.bloomberg. com/view/articles/2016-03-11/there-s-no-crisis-brewing-in-subpr ime-auto-loans.

Robb, C.A., et al. 2015. Bounded rationality and use of alternative financial services. Journal of Consumer Affairs 49 (2): 407-435. https://doi.org/10.1111/joca.12071.

Ryan, C. and J. M. Lewis. 2017. Computer and Internet Use in the United States: 2015 American Community Survey Reports. Available at: www.census.gov/acs. Accessed 22 Nov 2018.

Schkade, D.A., and D. Kahneman. 1998. Does living in california make people happy? A focusing illusion in judgements of life satisfaction. Psychological Science 9: 340-346.

Slovic, P. 1995. The construction of preference. American Psychologist 50 (5): 364-371. 
Strotz, A.R.H. 1955. Myopia and inconsistency in dynamic utility maximization. The Review of Economic Studies 23 (3): 165-180.

Thaler, R.H., and S. Benartzi. 2004. Save more tomorrow ${ }^{\mathrm{TM}}$ : Using behavioral economics to increase employee saving. Journal of Political Economy 112 (February): S164-S187.

Thaler, R.H., C.R. Sunstein, and J.P. Balz. 2010. Choice architecture. Social Science Research Network. https://doi.org/10.2139/ssrn. 1583509.

Tversky, A., P. Slovic, and D. Kahneman. 1990. The causes of preference reversal. The American Economic Review 80 (1): 204-217. https://doi.org/10.1126/science.151.3712.867-a.

Vihriälä, E. 2021. Commitment in debt repayment: evidence from a natural experiment. Working Paper. SSRN 3792708.

Vlaev, I., et al. 2011. Does the brain calculate value? Trends in Cognitive Sciences 15 (11): 546-554

Weber, E.U., and E.J. Johnson. 2009. Mindful judgment and decision making. Annual Review of Psychology 60: 53-85. https://doi.org/ 10.1146/annurev.psych.60.110707.163633.

Xiao, J.J., and R. Yao. 2014. Consumer debt delinquency by family lifecycle categories. International Journal of Bank Marketing 32 (1): 43-59. https://doi.org/10.1108/IJBM-02-2013-0007.

Publisher's Note Springer Nature remains neutral with regard to jurisdictional claims in published maps and institutional affiliations.
Linda Dezső is an Assistant Professor at the Vienna Center for Experimental Economics. She received her Ph.D. in applied psychology in 2017 from the University of Vienna. She has been conducting research at the intersection of psychology and economics, focusing on laboratory studies. Her work covers empirical studies on distributive preferences, bargaining behavior, self-serving fairness beliefs, and intertemporal choices.

Barna Bakó is an Associate Professor of Economics at Corvinus University of Budapest, Hungary. His current research focuses on behavioral economics, industrial organization, and game theory.

Gábor Neszveda (Ph.D., Tilburg University, the Netherlands) is an Associate Professor of Economics at the John von Neumann University, Hungary. He is also a senior researcher at the Central Bank of Hungary. His research focuses on behavioral economics, empirical asset pricing, behavioral finance, and sustainability. 